\title{
Optimasi Penempatan Distribution Generation pada Penyulang Pujon Menggunakan Metode Particle Swarm Optimization
}

\author{
Mas Ahmad Baihaqi ${ }^{1}$, Rini Nur Hasanah ${ }^{2}$, Hadi Suyono ${ }^{3}$ \\ 1,2,3 Jurusan Teknik Elektro, Fakultas Teknik, Universitas Brawijaya \\ masahmadbaihaqi@gmail.com, rini.hasanah@ub.ac.id, hadis@ub.ac.id
}

\begin{abstract}
This study proposes the use of Particle Swarm Optimization (PSO) algorithm to optimize the placement of Distributed Generation (DG) on the $20 \mathrm{kV}$ distribution system of Pujon feeder, which has 117 buses with the total distribution line length of 59.65 kilometers, with the aim to reduce power losses. In addition, PSO has also been used to determine the capacity of the DG. The JAYA algorithm is used as comparison. It has been proven that the proposed algorithm as well as the comparison algorithm succeeded in determining the optimum location and the capacity of DG to be installed.
\end{abstract}

Keywords : JAYA Algorithm, Distributed Generation, DG injection, Distribution Network, Particle Swarm Optimization

\section{INTISARI}

Pada penelitian ini diusulkan penggunaan algoritma Particle Swarm Optimization (PSO) sebagai metode optimasi dalam peletakan Distributed Generation (DG) pada sistem distribusi 20kV penyulang Pujon yang mempunyai 117 bus dengan panjang saluran 59,65 km, dengan tujuan untuk mengurangi rugi-rugi daya. Selain itu, PSO juga digunakan untuk menentukan besar kapasitas DG yang akan dipasang. Algoritma JAYA digunakan sebagai algoritma pembanding PSO. Algoritma yang diusulkan maupun pembandingnya terbukti berhasil menentukan titik lokasi dan besar kapasitas DG yang akan dipasang.

Kata kunci: Algoritma JAYA, Distributed Generation, Injeksi DG, Jaringan Distribusi, Particle Swarm Optimization

\section{PENDAHULUAN}

Sistem pembangkit dengan jumlah bus yang banyak menimbulkan masalah tersendiri dalam penentuan lokasi unit Distributed Generation (DG) yang akan di pasang. Kesalahan dalam penentuan daya keluaran dan jumlah unit DG yang akan ditempatkan berpengaruh terhadap keandalan unit DG dan rugi daya pada jaringan listrik. Permasalahan penempatan DG yang optimal dapat diselesaikan dengan menggunakan pemrograman nonlinier gabungan, yang selama ini telah dipecahkan dengan berbagai metode analisis numerik dan heuristic. [1]

Penempatan DG secara signifikan sangat mempengaruhi operasi jaringan distribusi. Penempatan DG yang tidak tepat dapat menyebabkan modal sistem dan biaya operasional serta kerugian jaringan menjadi lebih besar. Di sisi lain, penempatan DG yang optimal bisa membantu menjaga profil tegangan dalam batas yang ditentukan, dapat mengurangi rugi pada aliran daya di jaringan distribusi, serta dapat meningkatkan kualitas daya dan keandalan pasokan daya listrik. [2]

Jika sumber DG ditempatkan pada lokasi yang optimal maka kinerja jaringan dapat ditingkatkan secara signifikan, baik dalam hal perbaikan profil tegangan, pengurangan kerugian serta peningkatan kualitas daya dan keandalan sistem.

Permasalahan optimasi dapat diselesaikan dengan meggunakan metode Particle Swarm Optimization (PSO), dengan tujuan untuk mengoptimalkan variabel daya beban dengan faktor daya kurang dari satu [3]. Peningkatan unjuk kerja algoritma PSO dapat dilakukan menggunakan konsep PSO hibridisasi, seperti 
Jurnal ECOTIPE, Volume 7, No.1, April 2020, Hal. 38-46

p-ISSN 2355-5068, e-ISSN 2622-4852

Akreditasi Kemenristekdikti (SINTA 4), SK. No.10/E/KPT/2019

DOI: 10.33019/ecotipe.v7i1.1650

yang ditempuh dengan menggabungkan Genetic Algorithm (GA) [4][5].

Pada penelitian ini metode PSO diperkuat dengan algoritma JAYA untuk penentuan letak dan kapasitas optimal DG. Algoritma Jaya dikenal memiliki kelebihan tidak membutuhkan parameter algoritma yang spesifik dan solusi yang diperoleh bergerak menuju solusi terbaik dan menghindari solusi terburuk [6]. PSO dan JAYA merupakan sebagian dari metode optimasi yang sederhana dan mudah diimplementasikan. [1][2][3][6][7][8][9]

\section{METODE PENELITIAN}

Sebelum dapat dilakukan optimasi, pada sistem distribusi yang ada perlu dilakukan analisis aliran daya. Untuk meningkatkan keakuratan, kemudahan dan kecepatan perhitungan, pengembangan terhadap metode forward-backward yang banyak digunakan seringkali dilakukan [10]. Pada penelitian ini digunakan metode $Z_{B R}$, yang merupakan metode yang digunakan untuk membentuk persamaan aliran daya dengan menyusun impedansi saluran distribusi radial dalam suatu matrik untuk menghitung drop tegangan [11].

Matriks $Z_{B R}$ merupakan matriks yang merepresentasikan impedansi saluran satu fasa yang dibentuk dengan menelusuri jalur arus mengalir ke beban dan dikonversikan kedalam matriks sesuai dengan nilai impedansi.

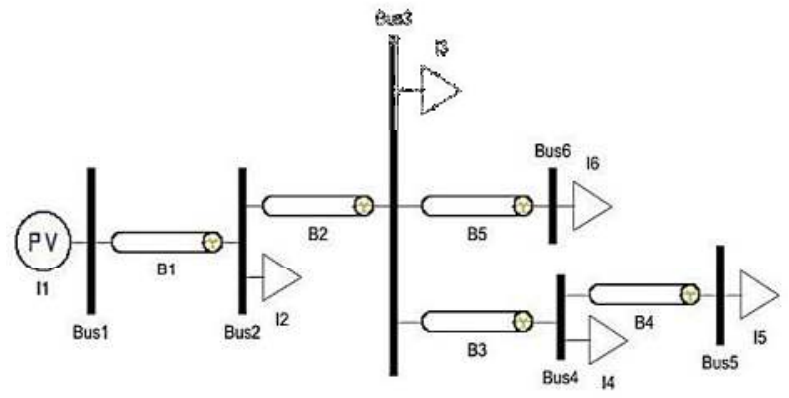

Gambar 1. Single-line diagram dengan metode network topology
Sebelum membentuk matrik $Z_{B R}$, digunakan metode network topology untuk mendapatkan persamaan analisis aliran daya, berdasarkan single-line diagram seperti yang dicontohkan pada Gambar 1

Pada Gambar 1 ditampilkan sistem distribusi sederhana dengan model rangkaian radial murni disuplai dari satu sumber pada infinite bus yang menyuplai beban yang tersebar dengan jalur tertentu. Berdasarkan sistem tersebut disusun persamaan sederhana (1)-(5).

$$
\begin{aligned}
& B_{5}=I_{6} \\
& B_{4}=I_{5} \\
& B_{3}=I_{4}+I_{5} \\
& B_{2}=I_{3}+I_{4}+I_{5}+I_{6} \\
& B_{1}=I_{2}+I_{3}+I_{4}+I_{5}+I_{6}
\end{aligned}
$$

Persamaan injeksi arus ke bus (1)-(5) dapat ditampilkan secara lebih ringkas dalam bentuk matriks BIBC (Bus Injection to Branch Current)

$$
\begin{aligned}
{\left[\begin{array}{l}
B_{1} \\
B_{2} \\
B_{3} \\
B_{4} \\
B_{5}
\end{array}\right] } & =\left[\begin{array}{lllll}
1 & 1 & 1 & 1 & 1 \\
0 & 1 & 1 & 1 & 1 \\
0 & 0 & 1 & 1 & 0 \\
0 & 0 & 0 & 1 & 0 \\
0 & 0 & 0 & 0 & 1
\end{array}\right]\left[\begin{array}{l}
I_{2} \\
I_{3} \\
I_{4} \\
I_{5} \\
I_{6}
\end{array}\right] \\
{[B] } & =[B I B C][I]
\end{aligned}
$$

Nilai drop tegangan berdasarkan jalur injeksi arusnya dapat dibentuk melalui persamaan (8)(11).

$$
\begin{aligned}
V_{2} & =V_{1}-B_{1} \cdot Z_{12} \\
V_{3} & =V_{1}-B_{1} \cdot Z_{12}-B_{2} \cdot Z_{23} \\
V_{4} & =V_{1}-B_{1} \cdot Z_{12}-B_{2} \cdot Z_{23}-B_{3} \cdot Z_{34} \\
V_{5} & =V_{1}-B_{1} \cdot Z_{12}-B_{2} \cdot Z_{23}-B_{3} \cdot Z_{34}-B_{4} \cdot Z_{45} \\
V_{6} & =V_{1}-B_{1} \cdot Z_{12}-B_{2} \cdot Z_{23}-B_{3} \cdot Z_{36}
\end{aligned}
$$

Selanjutnya masing-masing persamaan (8)(12) dapat dituliskan seperti (13)-(17):

$$
\begin{aligned}
& V_{1}=V_{2}-B_{1} \cdot Z_{12} \\
& V_{1}=V_{3}-B_{1} \cdot Z_{12}-B_{2} \cdot Z_{23} \\
& V_{1}=V_{4}-B_{1} \cdot Z_{12}-B_{2} \cdot Z_{23}-B_{3} \cdot Z_{34} \\
& V_{1}=V_{5}-B_{1} \cdot Z_{12}-B_{2} \cdot Z_{23}-B_{3} \cdot Z_{34}-B_{4} \cdot Z_{45} \\
& V_{1}=V_{6}-B_{1} \cdot Z_{12}-B_{2} \cdot Z_{23}-B_{3} \cdot Z_{36}
\end{aligned}
$$


Jurnal ECOTIPE, Volume 7, No.1, April 2020, Hal. 38-46

p-ISSN 2355-5068, e-ISSN 2622-4852

Akreditasi Kemenristekdikti (SINTA 4), SK. No.10/E/KPT/2019

DOI: 10.33019/ecotipe.v7i1.1650

Persamaan (13)-(17) dapat dibentuk dan diselesaikan menggunakan komponen matriks BCBV (Branch Current to Branch Voltage) (18)(19).

$$
\begin{aligned}
{\left[\begin{array}{c}
V_{1}-V_{2} \\
V_{1}-V_{3} \\
V_{1}-V_{4} \\
V_{1}-V_{5} \\
V_{1}-V_{6}
\end{array}\right] } & =\left[\begin{array}{ccccc}
Z_{12} & 0 & 0 & 0 & 0 \\
Z_{12} & Z_{23} & 0 & 0 & 0 \\
Z_{12} & Z_{23} & Z_{34} & 0 & 0 \\
Z_{12} & Z_{23} & Z_{34} & Z_{45} & 0 \\
Z_{12} & Z_{23} & 0 & 0 & Z_{36}
\end{array}\right]\left[\begin{array}{l}
B_{1} \\
B_{2} \\
B_{3} \\
B_{4} \\
B_{5}
\end{array}\right] \\
{[\Delta V] } & =[B C B V][B]
\end{aligned}
$$

Nilai total rugi daya aktif pada sistem distribusi dinyatakan menggunakan persamaan (20).

$$
P_{T L}=\sum_{i=1}^{n} I_{i}^{2} R_{i}
$$

dengan:

$n$ adalah jumlah cabang saluran pada sistem distribusi

$I_{\mathrm{i}}$ adalah nilai magnitude arus

$R_{\mathrm{i}}$ adalah resistansi

Pada penyulang Pujon khususnya, ada potensi hybrid surya-angin yang terdiri dari 117 bus dengan total panjang saluran $59,65 \mathrm{~km}$, bekerja pada tegangan $20 \mathrm{kV}$ [12].

Perhitungan penentuan kapasitas DG pada penelitian ini dilakukan dengan mencari batas maksimum dan batas minimum DG, baik kapasitas daya aktif $(P)$ maupun daya reaktif $(Q)$. Kapasitas daya aktif DG diperoleh dari total beban maksmimum pada sistem distribusi penyulang Pujon dengan nilai total 4,89 MW, sedangkan kapasitas daya reaktif dihitung dengan menggunakan metode segitiga daya seperti yang ditunjukkan pada Gambar 2.

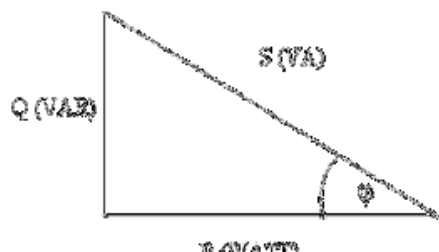

Gambar 2. Segitiga Daya
Berdasarkan metode segitiga daya dapat dipeoleh daya reaktif menggunakan persamaan (20).

$$
\tan \varphi=\frac{Q}{P}
$$

Algoritma PSO dan JAYA digunakan pada proses optimasi penempatan dan penentuan kapasitas DG. Penentuan titik pada bus yang optimal dan kapasitas optimal DG pada sistem distribusi penyulang Pujon dilakukan dengan tujuan untuk meminimalisir rugi-rugi daya aktif pada sistem. Pengolahan data dan simulasi dikerjakan dengan menggunakan alat bantu prinati lunak Matlab.

Langkah awal dilakukan dengan menentukan kapasitas optimal DG pada semua titik sebagai kasus dasar dan salah satu yang terbaik dipilih berdasarkan prinsip maximum loss saving [13]. Unit DG yang memiliki nilai $P_{\text {loss }}$ sistem terendah menjadi kandidat untuk lokasi penempatan DG. Ketika telah ditemukan bus yang optimal untuk peletakan DG, analisis aliran daya digunakan untuk menghitung nilai rugi daya dan tegangan yang baru.

Perumusan matematika masalah optimasi untuk aplikasi unit DG dinyatakan menggunakan persamaan (21)-(24).

1. Fungsi obyektif yang digunakan untuk penentuan letak dan kapasitas DG terpasang dinyatakan oleh persamaan (21).

$$
\text { Obj.Fuction }=\min \sum_{i=1}^{n} P_{\text {loss }}
$$

dengan $P_{\text {loss }}$ adalah total kerugian daya aktif pada sistem, seperti dinyatakan dengan persamaan (22).

$$
P_{\mathrm{loss}}=\sum_{i=1}^{n} I_{i}^{2} R_{i}
$$

dengan

$I_{i}=$ magnitude arus

$R_{i}=$ resistansi 
Jurnal ECOTIPE, Volume 7, No.1, April 2020, Hal. 38-46

p-ISSN 2355-5068, e-ISSN 2622-4852

Akreditasi Kemenristekdikti (SINTA 4), SK. No.10/E/KPT/2019

DOI: 10.33019/ecotipe.v7i1.1650

2. Batasan tegangan yang dijinkan berada pada $\pm 5 \%$ tegangan nominal, sebagaimana dinyatakan pada (23).

$$
V_{\min } \leq V_{i} \leq V_{\max }
$$

dengan

$i=$ nomer bus $\quad$ untuk $\mathrm{i}=1,2,3, \ldots, \mathrm{n}$

$\mathrm{V}_{\text {min }}=0.95$ p.u.

$\mathrm{V}_{\text {maks }}=1.05$ p.u.

3. $P_{D G} \min \leq P_{D G} \leq P_{D G} \max$

Bagan alir implementasi algoritma PSO untuk optimasi DG ditunjukkan pada Gambar 3, sedangkan dengan menggunakan algoritma JAYA ditunjukkan pada Gambar 4.

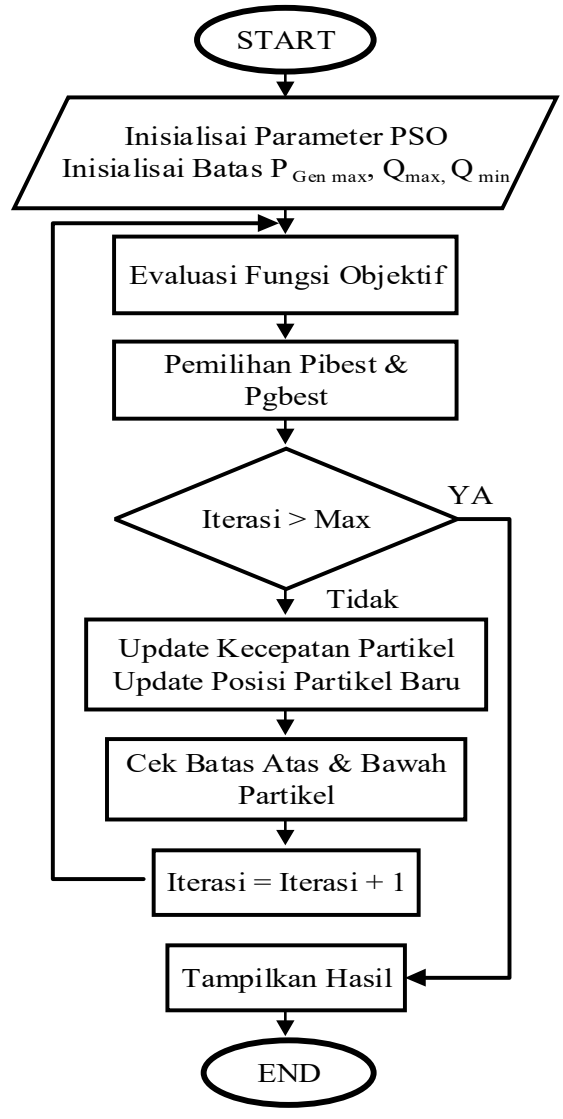

Gambar 3. Implementasi algoritma PSO untuk optimasi DG
Seperti ditunjukkan pada Gambar 3, langkah pertama adalah inisialisasi jumlah populasi, yaitu 20. Inisialisasi kedua adalah penentuan maksimum iterasi, yaitu 50. Parameter konstanta cognitive dan social acceleration PSO masingmasing ditetapkan bernilai 2. Penentuan batas maksimum generator yang di pakai mengacu pada jumlah maksimum beban pada penyulang Pujon yaitu sebesar 4,89 MW dengan batas bawah atau minimum generator yang dipakai bernilai sebesar 0,1 MW. Batas maksimum pada $Q_{\max }$ adalah 3,02 dan nilai minimum $Q_{\min }$ adalah 3,02 .

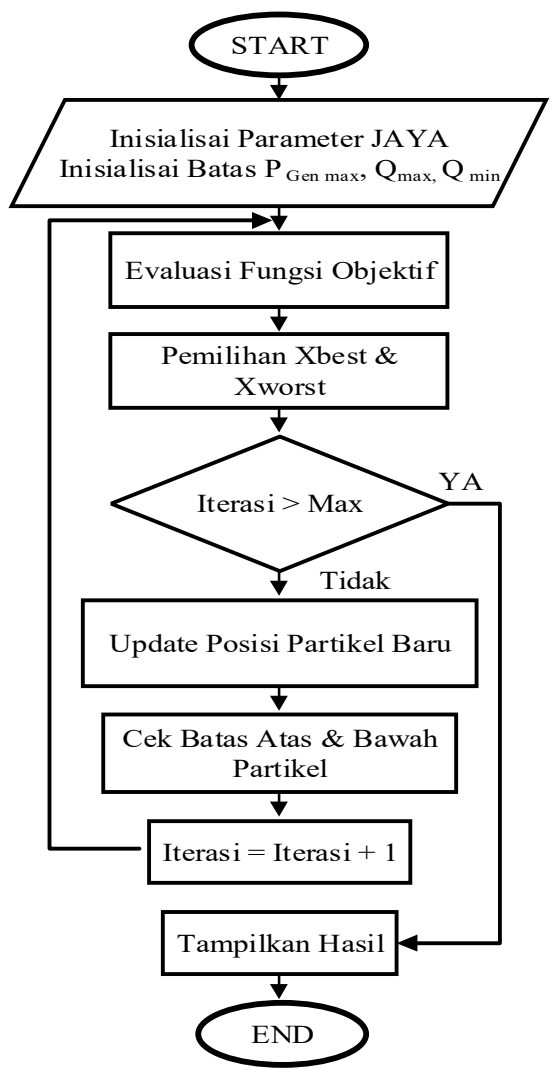

Gambar 4. Implementasi algoritma JAYA untuk optimasi DG

Langkah kedua yaitu mengevaluasi fungsi objektif seperti pada persamaan (21). langkah ketiga menentukan partikel terbaik individu $P_{\text {ibest }}$ 
Jurnal ECOTIPE, Volume 7, No.1, April 2020, Hal. 38-46

p-ISSN 2355-5068, e-ISSN 2622-4852

Akreditasi Kemenristekdikti (SINTA 4), SK. No.10/E/KPT/2019

DOI: 10.33019/ecotipe.v7i1.1650

dan partikel terbaik global $P_{\text {gbest, }}$ dilanjutkan dengan mengecek jumlah iterasi apakah sudah melebihi jumlah yang ditentukan. Jika belum, dilakukan update kecepatan partikel dan posisi partikel baru, dilanjutkan mengecek batas atas dan batas bawah dari partikel. Iterasi dilakukan hingga mencapai jumlah iterasi yang ditentukan, yaitu maksimum iterasi sebanyak 50 kali, sebelum hasilnya ditampilkan

Sebagaimana terlihat pada Gambar 4, implementasi algoritma Jaya mirip dengan penggunaan algoritma PSO. Perbedaan terletak pada tidak adanya langkah update kecepatan partikel.

\section{HASIL PENELITIAN DAN PEMBAHASAN}

Simulasi yang dilakukan untuk mengkaji penentuan titik optimal penambahan DG dan penentuan kapasitas ukurannya didasari tujuan untuk mengurangi rugi-rugi pada penyulang Pujon yang terdiri dari 117 bus pada Gardu Induk Sengkaling, seperti pada Gambar 5.

\section{A. Hasil Analisis Aliran Daya}

Analisis aliran daya dengan metode $Z_{\mathrm{BR}}$ dilakukan menggunakan nilai-nilai sebagai berikut:

- Base tegangan $=20 \mathrm{kV}$

- Base daya = $30 \mathrm{MVA}$

- Akurasi $=0.000001$

Hasil analisis aliran daya pada tiap-tiap bus sistem eksisting Penyulang Pujon menggunakan software Matlab dengan metode NewtonRaphson ditunjukkan pada Gambar 6.

Gambar 6 menunjukkan profil tegangan (dalam satuan p.u.) sebelum dilakukan injeksi DG. Terlihat bahwa tegangan jatuh pada bus kedua terhadap bus pertama cukup tinggi di bandingkan dengan tegangan jatuh pada bus ketiga terhadap bus kedua. Hal ini terjadi karena impedasi saluran antara bus ke-1 dan ke-2 jauh lebih tinggi dibandingkan dengan impedansi saluran antara bus ke-2 dan ke-3. Bus paling jauh terhadap sumber memiliki profil tegangan yang paling rendah yaitu sebesar 0,915 p.u yang terletak pada bus ke- 113 sampai bus ke-117.

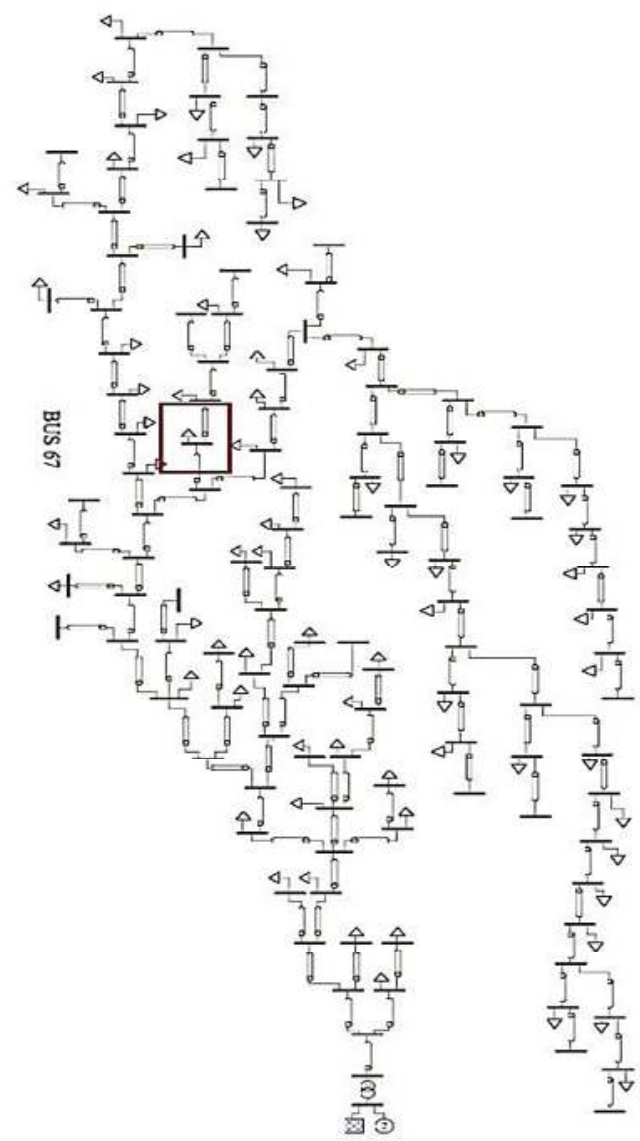

Gambar 5. Single-line diagram Penyulang Pujon 117 Bus

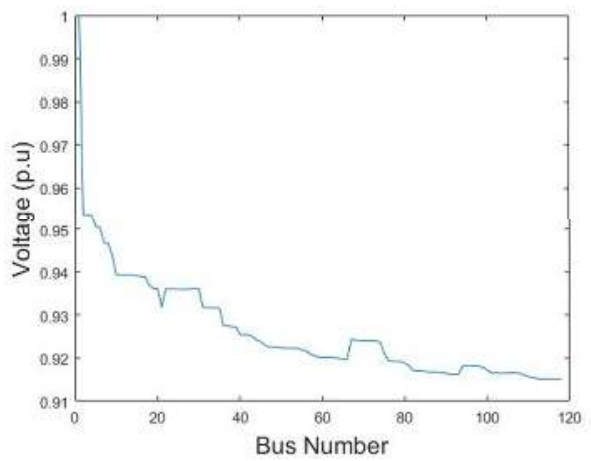

Gambar 6. Profil tegangan sebelum injeksi DG sebagai fungsi nomor bus 
Jurnal ECOTIPE, Volume 7, No.1, April 2020, Hal. 38-46

p-ISSN 2355-5068, e-ISSN 2622-4852

Akreditasi Kemenristekdikti (SINTA 4), SK. No.10/E/KPT/2019

DOI: 10.33019/ecotipe.v7i1.1650

Dari hasil analisis aliran daya menggunakan metode Newton Raphson diperoleh rugi-rugi daya aktif sebesar 0,134 MW dan rugi-rugi daya reaktif sebesar 0,235 MVAr. Dengan daya aktif pada generator sebesar 4.469 MW dan daya reaktif pada generator sebesar 2.809 MVAr, maka prosentase rugi-rugi daya sebelum ada penambahan injeksi DG sebesar $2.9 \%$ untuk daya aktif dan sebesar $8.3 \%$ untuk rugi-rugi daya reaktif.

\section{B. Optimasi Penambahan DG Berbasis PSO}

Pada tahap ini dilakukan pemasangan DG pada sistem distribusi radial 117 bus. Pemasangan DG bertujuan untuk meminimalkan rugi-rugi daya pada jaringan distribusi Penyulang Pujon. Pengoptimalan DG ini dilakukan dengan menggunakan metode PSO untuk penentuan lokasi dan kapasitas DG.

Berdasarkan flowchart implementasi algoritma PSO untuk optimasi DG pada Gambar 3, metode PSO digunakan untuk mencari titik peletakan dan kapasitas DG yang optimal pada sistem 117 bus pada penyulang Pujon GI Sengkaling.

Pencarian nilai optimal kapasitas DG ditentukan dalam rentang 0,1 - 4,89 MW. Hasil terbaik dalam penentuan lokasi peletakan dan kapasitas DG diindikasikan oleh nilai rugi-rugi daya Ploss terendah. Untuk mendapatkan nilai total rugi-rugi, iterasi dilakukan sebanyak 50 kali, yang memberikan hasil seperti pada Tabel 1.

Tabel 1. Hasil 10 kali percobaan running program PSO

\begin{tabular}{|c|c|c|c|c|c|c|}
\hline \multirow{2}{*}{ No } & \multirow{3}{*}{ Bus } & \multicolumn{2}{|c|}{ Total Losess } & \multicolumn{3}{c|}{ DG } \\
\cline { 3 - 7 } & & $\begin{array}{c}\text { Aktif } \\
\text { (MW) }\end{array}$ & $\begin{array}{c}\text { Reaktif } \\
\text { (MVAr) }\end{array}$ & $\begin{array}{c}\text { P } \\
\text { (MW) }\end{array}$ & $\begin{array}{c}\text { Qmin } \\
\text { (MVAr) }\end{array}$ & $\begin{array}{c}\text { Qmax } \\
\text { (MVAr) }\end{array}$ \\
\hline 1 & 67 & 0.019 & 0.015 & 3.751 & -0.100 & 2.816 \\
\hline 2 & 67 & 0.019 & 0.015 & 3.787 & -0.100 & 1.495 \\
\hline 3 & 67 & 0.019 & 0.015 & 3.819 & -0.100 & 0.100 \\
\hline 4 & 67 & 0.019 & 0.015 & 3.740 & -0.100 & 2.327 \\
\hline 5 & 67 & 0.019 & 0.015 & 3.802 & -0.100 & 1.193 \\
\hline 6 & 67 & 0.019 & 0.015 & 3.794 & -0.100 & 0.253 \\
\hline 7 & 67 & 0.019 & 0.015 & 3.788 & -0.100 & 0.276 \\
\hline 8 & 67 & 0.019 & 0.015 & 3.807 & -0.100 & 3.020 \\
\hline 9 & 67 & 0.019 & 0.015 & 3.796 & -0.100 & 1.950 \\
\hline 10 & 67 & 0.019 & 0.015 & 3.789 & -0.100 & 0.100 \\
\hline
\end{tabular}

Tabel 1 menunjukkan hasil 10 kali percobaan running program PSO. Dapat terlihat bahwa hasil optimasi lokasi diperoleh pada bus 67 dengan total rugi-rugi daya aktif sebesar 0,019 MW dan pada total losses daya reaktif sebesar 0,015 MVAr, dengan kapasitas generator sebesar 3,807 MW, $Q_{\text {min }}$ sebesar -0,100 MVAr dan $Q_{\max }$ sebesar 3,020 MVAr

Gambar 7 menunjukkan hasil perbandingan antara profil tegangan sebelum ada injeksi DG dengan setelah adanya injeksi DG.

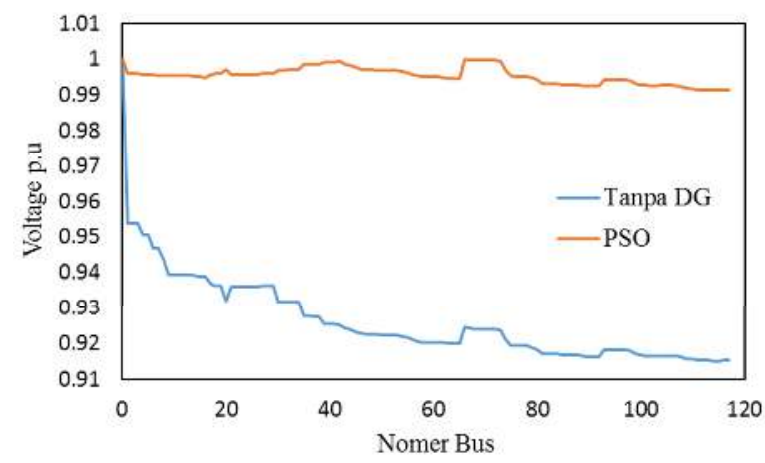

Gambar 7. Perbandingan profil tegangan sebelum dan setelah ada injeksi DG menggunakan metode PSO

Sebelum ada injeksi DG, perbedaan tegangan jatuh antara bus kedua dan pertama dengan antara bus ketiga dan bus kedua cukup tinggi. Hal ini dikarenakan impedasi saluran antara bus ke-1 dan ke-2 jauh lebih tinggi dibandingkan dengan impedansi saluran antara bus ke-2 dan ke-3. Bus paling jauh terhadap sumber memiliki profil tegangan yang paling rendah. Setelah ada penambahan DG, perbedaan antara tegangan jatuh bus yang paling jauh terhadap sumber semakin rendah pada profil tegangannya. Perbaikan profil tegangan dikarenakan adanya penambahan DG yang optimal dan rugi-rugi daya yang semakin menurun.

Besarnya rugi-rugi daya pada setiap tahap iterasi perhitungan ditunjukkan pada Gambar 8. 
Jurnal ECOTIPE, Volume 7, No.1, April 2020, Hal. 38-46

p-ISSN 2355-5068, e-ISSN 2622-4852

Akreditasi Kemenristekdikti (SINTA 4), SK. No.10/E/KPT/2019

DOI: 10.33019/ecotipe.v7i1.1650

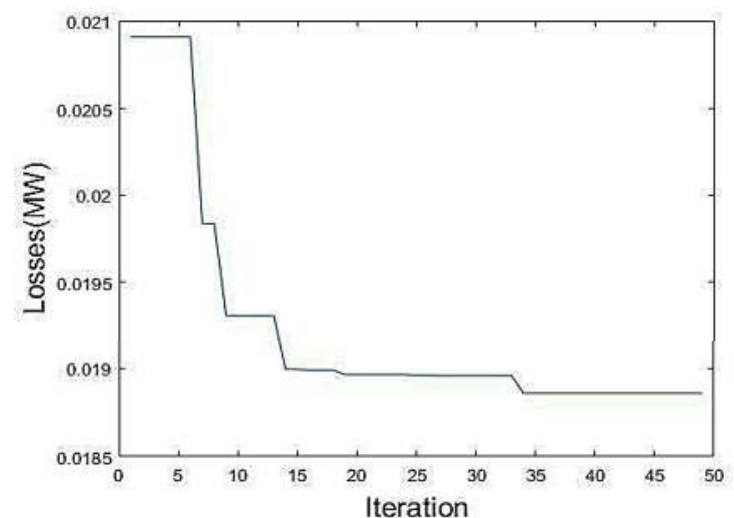

Gambar 8. Rugi-rugi daya pada tiap tahap iterasi perhitungan

Pada Gambar 8 ditunjukkan bahwa jika jumlah iterasi pada algoritma PSO semakin mendekati jumlah iterasi maksimum yang telah ditetapkan, yaitu 50 iterasi, maka rugi-rugi daya semakin kecil karena algoritma optimasi sudah berhasil menentukan hasil yang tepat untuk optimasi lokasi dan kapasitas DG.

\section{Optimasi Penambahan DG Berbasis JAYA}

Pengoptimalan DG dengan menggunakan metode JAYA untuk penentuan lokasi dan kapasitas DG dilakukan berdasarkan diagram alir implementasi algoritma JAYA Gambar 4. Metode optimasi JAYA digunakan untuk mencari titik peletakan lokasi dan kapasitas DG yang optimal pada sistem 117 bus pada Penyulang Pujon GI Sengkaling. Besarnya kapasitas DG juga dicari dalam rentang 0,1-4,89 MW. Hasil yang terbaik ditentukan oleh nilai Ploss yang terendah. Untuk mendapatkan total losses dilakukan sebanyak 50 kali iterasi, dengan hasil sebagaimana ditunjukkan pada Tabel 2.
Tabel 2. Hasil 10 kali percobaan running program JAYA

\begin{tabular}{|c|c|c|c|c|c|c|}
\hline \multirow{2}{*}{ no } & \multirow{2}{*}{ BUS } & \multicolumn{2}{|c|}{ Total Losess } & \multicolumn{3}{c|}{ DG } \\
\cline { 3 - 7 } & $\begin{array}{c}\text { Aktif } \\
\text { (MW) }\end{array}$ & $\begin{array}{c}\text { Reaktif } \\
\text { (MVAr) }\end{array}$ & $\begin{array}{c}\text { P } \\
\text { (MW) }\end{array}$ & $\begin{array}{c}\text { Qmin } \\
\text { (MVAr) }\end{array}$ & $\begin{array}{c}\text { Qmax } \\
\text { (MVAr) }\end{array}$ \\
\hline 1 & 67 & 0.019 & 0.015 & 3.802 & -0.734 & 0.234 \\
\hline 2 & 67 & 0.019 & 0.015 & 3.716 & -0.851 & 2.397 \\
\hline 3 & 43 & 0.019 & 0.015 & 3.828 & -0.309 & 0.718 \\
\hline 4 & 67 & 0.019 & 0.015 & 3.760 & -0.564 & 0.786 \\
\hline 5 & 67 & 0.019 & 0.015 & 3.767 & -0.867 & 0.355 \\
\hline 6 & 67 & 0.019 & 0.015 & 3.765 & -0.275 & 0.108 \\
\hline 7 & 67 & 0.019 & 0.015 & 3.777 & -0.100 & 2.056 \\
\hline 8 & 67 & 0.019 & 0.015 & 3.809 & -0.100 & 1.361 \\
\hline 9 & 67 & 0.019 & 0.015 & 3.734 & -0.244 & 0.447 \\
\hline 10 & 67 & 0.019 & 0.015 & 3.736 & -0.105 & 3.020 \\
\hline
\end{tabular}

Tabel 2 menampilkan hasil 10 kali percobaan running program JAYA. Hasil optimasi memberikan lokasi optimal pada bus 67 dan sekali pada bus 43 dengan total losses daya aktif 0,019 MW dan pada total losses daya reaktif 0,015 MVAr dengan besar kapasitas generator 3,736 MW, $Q_{\min }-0,105 \mathrm{MVAr}$ dan $Q_{\max } 3,020$ MVAr.

Gambar 9 menunjukkan perbandingan profil tegangan sebelum dan sesudah ada injeksi DG menggunakan metode berbasis JAYA.

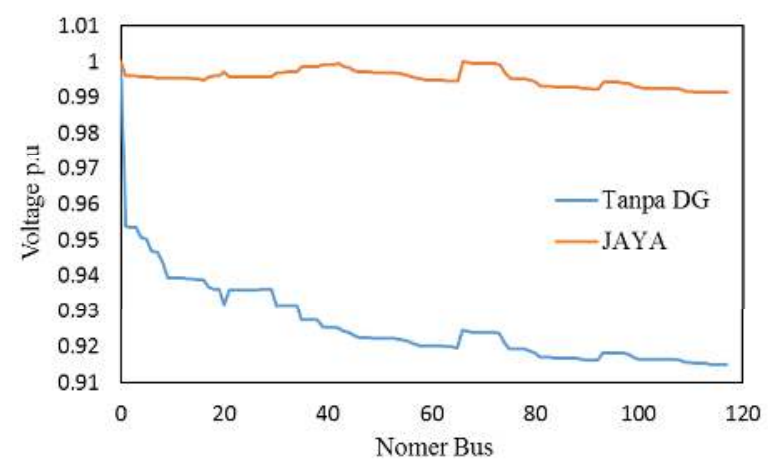

Gambar 9. Perbandingan profil tegangan sebelum dan sesudah ada injeksi DG menggunakan metode berbasis JAYA

Dapat dilihat dari Gambar 9 bahwa profil tegangan antara sebelum dan sesudah ada injeksi DG sangat berbeda. Sebelum ada injeksi DG, tegangan jatuh antara bus kedua dengan bus pertama cukup tinggi dibandingkan dengan tegangan jatuh antara bus ketiga dengan bus 
Jurnal ECOTIPE, Volume 7, No.1, April 2020, Hal. 38-46

p-ISSN 2355-5068, e-ISSN 2622-4852

Akreditasi Kemenristekdikti (SINTA 4), SK. No.10/E/KPT/2019

DOI: 10.33019/ecotipe.v7i1.1650

kedua. Hal ini dikarenakan impedasi saluran antara bus ke-1 dan ke-2 sangat tinggi dibandingkan dengan impedansi saluran antara bus ke-2 dan ke-3. Bus paling jauh terhadap sumber memiliki profil tegangan yang paling rendah. Setelah ada penambahan DG maka perubahan tegangan jatuh bus yang paling jauh terhadap sumber semakin rendah. Profil tegangannya mengalami peningkatan karena ada penambahan DG yang optimal dan rugi-rugi daya semakin menurun.

Besarnya rugi-rugi daya pada tiap-tiap iterasi ditunjukkan pada Gambar 10.

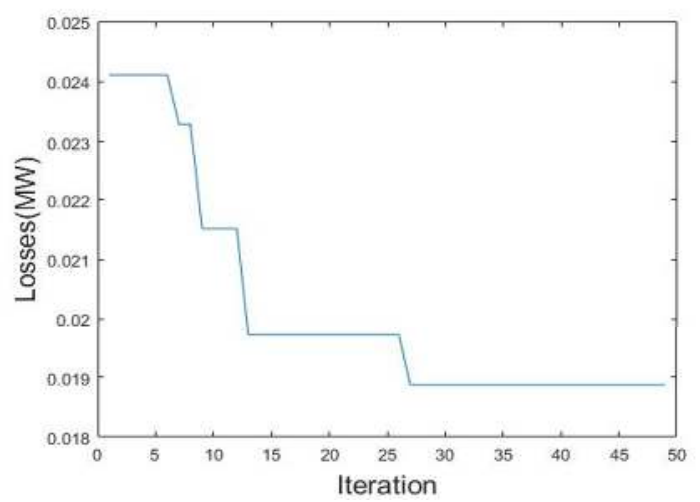

Gambar 10. Besarnya rugi-rugi daya pada tiap-tiap iterasi

Gambar 9 menunjukkan bahwa semakin banyak jumlah iterasi pada algoritma JAYA, semakin kecil besarnya losses. Hal ini menunjukkan algoritma optimasi JAYA sudah berhasil menentukan hasil yang tepat untuk optimasi dan kapasitas DG.

\section{KESIMPULAN}

Algoritm PSO dan JAYA dapat digunakan untuk menentukan titik optimal penempatan DG dan ukuran kapasitasnya. Kedua metode optimasi yang digunakan menghasilkan titik optimal penempatan serta ukuran kapasitas distributed generator yang sama, yaitu pada bus 67 dengan kapasitas DG sebesar 3.834 MW. Injeksi DG dengan ukuran kapasitas serta penempatan pada lokasi optimal menggunakan metode PSO dan
JAYA dapat mengurangi rugi-rugi daya aktif sebesar $85,82 \%$, serta rugi-rugi daya reaktif sebesar 93,62\% dari sebelum injeksi DG pada sistem Penyulang Pujon.

Masih terbuka kemungkinan untuk menerapkan metode-metode lain dalam penentuan lokasi penempatan dan kapasitas DG untuk diinjeksikan dalam sistem distribusi.

\section{DAFTAR PUSTAKA}

[1] Georgilakis, P.S., Hatziargyriou, N.D. (2013). Optimal Distributed Generation Placement in Power Distribution Networks: Models, Methods, and Future Research.; IEEE Transactions on Power Systems, vol.28, No.3.

[2] Niazi, G., Lalwani, M. (2017). PSO based optimal distributed generation placement and sizing in power distribution networks: A comprehensive review. Proceedings of the 2017 International Conference on Computer, Communications and Electronics (Comptelix).

[3] Rajalakshmi, J., Durairaj, S. (2016). Review on optimal distributed generation placement using Particle Swarm Optimization algorithms. Proceedings of the 2016 International Conference on Emerging Trends in Engineering, Technology and Science (ICETETS).

[4] Kerdchuen, T., Ongsakul, W. (2006). Optimal Measurement Placement for Power System State Estimation Using Hybrid Genetic Algorithm and Simulated Annealing. Proceedings of the 2006 International Conference on Power System Technology.

[5] Evangelopoulos, V.A., Georgilakis, P.S. (2014). Optimal distributed generation placement under uncertainties based on point estimate method embedded genetic algorithm. IET Generation, Transmission \& Distribution, vol.8, No.3. 
Jurnal ECOTIPE, Volume 7, No.1, April 2020, Hal. 38-46

p-ISSN 2355-5068, e-ISSN 2622-4852

Akreditasi Kemenristekdikti (SINTA 4), SK. No.10/E/KPT/2019

DOI: 10.33019/ecotipe.v7i1.1650

[6] Rao, R. V. (2016). Jaya: A simple and new optimization algorithm for solving constrained and unconstrained optimization problems. International Journal of Industrial Engineering Computations, vol.7.

[7] Kennedy, Eberhart, R. (1995). Particle Swarm Optimization. Proceedings of the IEEE Int. Conf on Neural Networks.

[8] El-Zonkoly, A.M. (2011). Optimal placement of multi-distributed generation units including different load models using particle swarm optimisation. IET Generation, Transmission \& Distribution, vol.5, No.7.

[9] Bhumkittipich, K., Phuangpornpitak, W. (2013). Optimal Placement and Sizing of Distributed Generation for Power Loss Reduction Using Particle Swarm Optimization. Energy Procedia, vol.34

[10] Zuhdy, I. (2016). Penentuan Lokasi dan Pembebanan Optimal Distributed Generation Menggunakan Metode Genetic Algorithm pada Microgrid Tegangan Menengah. Tesis Institut Teknologi Sepuluh Nopember, Surabaya

[11] Hadi, S. (2004). Power System Analysis (Second Edition). McGraw-Hill Education (Asia), Singapore.

[12] Hakim, L. (2016). Studi Kelayakan Pembangkit Listrik Tenaga Hybrid SuryaAngin Terhubung Grid di Gunung Banyak Kota Batu. Tesis Program Magister Teknik Elektro Universitas Brawijaya, Malang.

[13] Basyarach, N.A. (2017). Optimasi Lokasi dan Kapasitas Kapasitor pada Kondisi Beban Berubah Terhadap Waktu untuk Minimisasi Rugi-Rugi Energi menggunakan Algoritma Accelerated Particle Swarm Optimization. Tesis Institut Teknologi Sepuluh Nopember, Surabaya. 